\title{
Study of Sows Reproductive Performance in Kalasey Village Minahasa District
}

\author{
Ratri Retno Ifada ${ }^{1, *}$ and Anggella $\mathrm{T}$ Tombuku ${ }^{1}$ \\ ${ }^{1}$ North Sulawesi Assessment Institute Agricultural Technology
}

\begin{abstract}
This research was conducted to determine the reproductive performance of sows that are kept intensively at the level of smallholder farming. The research method used was a direct interview with pig farmers in Kalasey Village. The data obtained were analyzed descriptively. The results showed a birth rate (litter size) of around 12 piglets, 110 days of pregnancy, 21 days of estrous cycles with 42 hours of estrus duration. With these results, it can be concluded that the reproductive performance of sows in the Kalasey Village is relatively good and according to normal standards.
\end{abstract}

\section{Introduction}

Basically the goal of raising pigs is to produce meat and make a profit. Feed, disease and management will affect the resulting production. Pig is one of the livestock commodities that has great potential to be developed because it has its own advantages, including its fast growth rate $[4,11]$. Beside, pigs are one of the most efficient sources of meat and nutrition because pigs have a fairly high ration conversion, the percentage of pig carcasses is also quite high, reaching $65-80 \%$, compared to the percentage of the beef which is only $50-60 \%$, sheep and goat $45-55 \%$ and buffalo about $38 \%$. Pork has a higher fat content so that the energy value is high and the water content is lower $[3,7]$.

The reproductive ability of pigs is very high compared to other livestock, which can produce many children at each birth. Reproductive performance is one indicator of the success of the reproductive performance of pigs. Skills in detecting estrus and the process of marrying pigs are key to the success of livestock production and productivity. Reproductive performance often goes unnoticed because physically it does not show adverse symptoms such as infectious diseases or other animal diseases. However, if we observe and calculate it, it turns out that the economic losses are quite large. Reproductive performance is a general description of the success of an enterprise in the livestock sector. Without reproduction there will be no production, the rate and efficiency of reproduction will determine the level and efficiency of production [5].

Pardosi [13] states that the important factors in raising pigs are liter size, birth weight, number and weight of weaned chicks. In addition, the estrous cycle and the length of estrus also affect pig production. The pig nation according can also affect the litter size. Pig breeds known today include VDL (Veredeld Duits Landvarken), Duroc, Yorkshire,

*Corresponding author: ra3.ifada@gmail.com 
Landrace, Hampshire, Saddleback [3, 11]. However, the results of the study by Ohin [11] show that there is no difference in reproductive performance between Landrace and Duroc breeds.

Pig farming businesses in North Sulawesi continue to be developed in a sustainably manner because the need for pork is increasing with the development of restaurants and markets that sell pork [12]. The demand for pork is quite high, at around one million kilos per year. The pig population in North Sulawesi in 2018 reached 418,297 heads [2]. For Minahasa District, it reached 129,944 heads in 2019.

Therefore, to increase the population and production of pigs, a description of the reproductive performance of livestock is needed. To encourage this research, namely to see how the reproductive performance of sows in the farms in Kalasey Village. The pigs that are on the farm in Kalasey village are crossbreeds of several types of pigs. Among others, Duroc, Landrace and Yorkshire.

\section{Material and Method}

This research was conducted in Kalasey Village, Mandolang SubDistrict, Minahasa District, North Sulawesi Province. The research was conducted using a survey method. Retrieval of data with interview techniques using a questionnaire (list of questions). The data obtained were then tabulated using descriptive analysis.

\section{Result and Discussion}

Table 1. Average reproduction performance of sows in Kalasey village, Minahasa Regency

\begin{tabular}{|c|l|c|c|}
\hline No & \multicolumn{1}{|c|}{ Reproduction Performance } & Result & \multicolumn{1}{c|}{$\begin{array}{c}\text { Standard } \\
\text { Normal*) }\end{array}$} \\
\hline 1 & litter size & 12 & $10-15$ \\
\hline 2 & Length of Pregnancy & 110 days & $11-115$ days \\
\hline 3 & Estrous Cycle & 21 days & $19-21$ days \\
\hline 4 & Long Time of Estrus & 42 hours & $1-3$ days \\
\hline & \multicolumn{2}{|l}{} \\
\hline
\end{tabular}

Source: Toelihere (1985)

\subsection{Litter Size}

Litter size is the number of children born per parent per birth. The sows in Kalasey Village farms show birth rates that meet the standard on average. Factors that influence birth rates include the age of the mother, feed, hormones and stress during pregnancy. Observation of the correct detection of lust also affects the birth rate. Apart from factory feed, the feed used for pig farms in Kalasey Village is for sows and growers added with milled corn, concentrate and rice bran. Rice bran contains up to $12.9 \%$ protein and energy content of up to $2,875 \mathrm{~K}$.cal $/ \mathrm{kg}$. While the concentrate contains $38 \%$ protein and energy around 2900 $\mathrm{Kcal} / \mathrm{kg}[10]$.

Piglets on the farm in Kalasey Village are bred at around $7-8$ months in general. To increase the birth rate, pigs that have been bred for the first time are fed ad libitum before mating. However, for sows in the early stages of pregnancy, especially pigs, are not given large amounts of food during the first 2 weeks of pregnancy because it can increase the embryonic mortality rate [8]. 
Pig breeders in Kalasey Village generally refuse sows if they have given birth 5 - 6 times. Also, pigs will also be rejected if there is a decrease in the birth rate and reproductive disorders such as repeated matings, miscarriage (abortion).

\subsection{Pig Matting}

Pig mating on farms in Kalasey village is done naturally. According to [9, 6], marriage naturally will produce a higher litter size than marriage through artificial insemination. Female sows reach puberty at the age of 5 to 8 months with a mean of 6 months, while the recommended mean age for first marriage is 8 to 10. On the farm in Kalasey Village, the average pigs are bred at the age of $7-8$ months because breeders see that at that age the pig reproduction has developed and the bodyweight has met. Pregnant pigs are pigs that do not show lust after they are mated.

Farmer knowledge of pregnancy is very important, so that farmers can determine the proper care management and when it is approaching the time of birth the farmer can prepare the right cage and place during the gestation period, maintaining the cleanliness and health of the mother is very necessary for smooth operation until later delivery. Addition of feed during pregnancy can also meet the nutritional needs of sows and prospective young. In contrast to the addition of feed at the beginning of pregnancy which can result in embryo death [8].

\subsection{The Estrous Cycle}

Estrus or lust is a physiological condition of cattle that are ready to mate within a certain time. Estrus occurs due to the activity of the hormone estrogen produced by the ovaries. The estrus is characterized by changes in the behavior of pigs. The results showed that the breeders knew and were able to recognize these behavioral changes such as increased anxiety, riding other female pigs and decreased appetite and made a distinctive sound, swollen and reddened vulva and the presence of mucus that appeared on the sows' genital tract. If these signs are seen, it means that the pig is ready for mating. Pig breeders in Kalasey Village will breed piglets during the second or third estrous cycle. Because the number of eggs that ovulate is more than in the first estrous cycle.

The estrous cycle in pigs is a time interval, from the beginning of the first estrous period to the next estrous period. The estrous cycle consists of proestrus, estrus, metestrus and diestrus. The length of the pig estrous cycle is 21 days. Pigs will be mated no later than 42 hours after signs of estrus appear or are visible to obtain optimal results. Pigs should be mated before ovulation. Ovulation is the process of releasing a mature egg from the ovary and ready to be fertilized by spermatozoa from male pigs. Spermatozoa will be able to stay in the female reproductive tract for about 24 hours. If mating is done too early, the sperm arrive in the fallopian tube too early and may die before any eggs are released. If mated too slowly, the eggs are too mature (more than 6 hours) and will result in more than one sperm entering one egg and will result in what is called polyspermy (one egg is fertilized by more than one spermatozoa). Proper mating will produce more fertilized eggs[14].

For sows that have just given birth, piglets will be weaned at the age of $1-1.5$ months or when their body weight has reached about $10 \mathrm{~kg}$. Parent will be remarried $1.5-2$ months after giving birth. This is so that within 1 year, the sows can give birth to 2 times.

Mortality or mortality on farms in Kalasey Village is very low. About 1-2 head / year. The cause of death in newborn piglets was mostly due to being crushed or trampled by the sows. For adult pigs, it is usually due to animal bites such as centipedes, not because of 
disease. The disease that is often encountered is diarrhea. For treatment, breeders call the veterinarian.

If the reproductive performance of sows is not optimal, it will pose a risk factor for these pigs. The risk factors for these pigs can be either regular factors or performance factors. Common factors include high and low parity levels, high temperatures, decreased lactation feed intake, increased lactation length and a farrowing event. Meanwhile, the performance factors include light birth weight or low preweaning growing rate, foster-in or nurse sow practices, early orlate age at first-mating and farrowing stillborn piglets [17].

\section{Conclusion}

The results showed that the sows in Kalasey Village had reproductive performance according to normal standards and were classified as good.

\section{References}

1. Kaka. JIP. $2811-9$ (2018)

2. Agricultural Statistics (2019)

3. D. Aritonang, M. Silalahi. JITV $6138-44$ (2001)

4. Directorate General of Animal Husbandry. Livestock Animal and Health Statistic (2013)

5. Feradis. Reproduksi Ternak. (2014)

6. Frandson. Anatomi dan Fisiology Ternak. UGM Press (1993)

7. H. Prasetyo, I. B. K. Ardana, M. K. Budiasa. IMV 23261 - 268 (2013)

8. O. Purba, M. K. Budiasa, I. B. K. Ardana. IMV 32163 - 168 (2014)

9. Ligaya, I. T. A Tumbelaka, P. H Siagian. JIT 72145 - 146 (2007)

10. M.C. Timbulus, P.R.R.I. Montong, A.D. Mirah, S.E, Siswaosubroto JZ 372 (2017)

11. M. H. Ohin, P. Kune, J. N Kihe. 12130 - 134 (2014)

12. M. J. Sarajar, F. H. Elly, S. J. K Umboh. Zootec 392276 - 283 (2019)

13. Pardosi. The Effect of Moting between Three Breeds of Pigs on the Achievement of Children from Birth to Weaning. Tesis. (2004)

14. Sihombing. Ilmu ternak Babi (2006)

15. T. Saroinsong, A. N. Mekel, F. Luntungan, M. Budiman. JTT 533 - 36 (2019)

16. Toelihere. Fisiologi Reproduksi pada Ternak. (1985)

17. Y. Koketsu, S. Tani, R Lida. PHM 31 